\title{
Hepatitis B virus X protein downregulates expression of the miR- 16 family in malignant hepatocytes in vitro
}

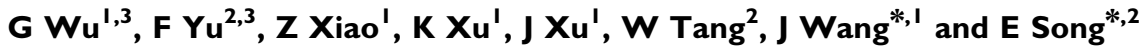 \\ 'Department of Hepatobiliary Surgery, Sun-Yat-Sen Memorial Hospital, Sun-Yat-Sen University, 107 Yanjiang West Road, Guangzhou 510120 , \\ People's Republic of China; 'Department of Breast Surgery, Sun-Yat-Sen Memorial Hospital, Sun-Yat-Sen University, 107 Yanjiang West Road, \\ Guangzhou 510120 , People's Republic of China
}

BACKGROUND: Hepatitis B virus X protein ( $\mathrm{HBX}$ ) is involved in the initiation and progression of hepatocellular carcinoma (HCC) by regulating the host protein-coding genes. In this study, we showed that $H B \times$ altered the expression of microRNAs (miRNAs) to promote proliferation and transformation in malignant hepatocytes in vitro.

METHODS: miRNA microarray and quantitative reverse-transcription polymerase chain reactions (qRT-PCRs) were performed to identify miRNAs that were differentially regulated by $\mathrm{HBx}$ in HCC cells. Protein, mRNA, and miRNA expression analyses; cell cycle and apoptosis analyses; loss/gain-of-function analysis; and luciferase reporter assays were performed to delineate the consequences of miR- 16 family repression in HepG2 cells.

RESULTS: Hepatitis B virus X protein induced widespread deregulation of miRNAs in HepG2 cells, and the downregulation of the miR- I 6 family was reproducible in HepG2, SK-HEP-I, and Huh7 cells. CCND I, a target of the miR- I 6 family, was derepressed by HBx in HepG2 cells. c-Myc mediated the HBx-induced repression of miR-I5a/I6 in HepG2 cells. Ectopically expressed miR- I5a/I6 suppressed the proliferation, clonogenicity, and anchorage-independent growth of HBx-expressing HepG2 cells by arresting them in the GI phase and inducing apoptosis, whereas reduced expression of miR-16 accelerated the growth and cell-cycle progression of HepG2 cells.

CONCLUSIONS: Hepatitis B virus $X$ protein altered the in vitro expression of miRNAs in host malignant hepatocytes, particularly downregulating the miR- 16 family. Repression of miR-15a/I 6 is c-Myc mediated and is required for the HBx-induced transformation of HepG2 cells in vitro. Therefore, miR- 16 family may serve as a therapeutic target for hepatitis B virus (HBV)-associated HCC. British Journal of Cancer (20I I) 1 05, I46- I53. doi:I0.1038/bjc.20 I I.190 www.bjcancer.com

Published online 3I May 20II

(c) 20II Cancer Research UK

Keywords: HBx; miRNAs; miR-16 family; c-Myc; hepatocellular carcinoma

Chronic hepatitis B virus (HBV) infection is the leading cause of hepatocellular carcinoma (HCC) in Asia and West Africa (El-Serag and Rudolph, 2007). In addition, HBV-infected HCCs exhibit more aggressive biological characteristics during clinical disease progression than do non-infected tumours. Hepatitis $\mathrm{B}$ virus $\mathrm{X}$ protein $(\mathrm{HBx})$, an oncoprotein encoded by HBV, has been confirmed to have a role in HBV-related hepatocarcinogenesis (Arbuthnot et al, 2000). It is a transactivating protein that alters host gene expression by constitutively activating cytoplasmic signal transduction pathways (e.g., NF- $\kappa$ B, Src, Ras, AP-1, AP-2, PI3K/Akt, Jak/STAT, Smad, and Wnt) and by binding to nuclear transcription factors (e.g., CREB, ATF-2, Oct-1, TBP, and basal transcription factors), contributing to increased cell proliferation and survival (Feitelson and Lee, 2007). It has been reported that HBx expression promotes HCC in mice (Kim et al, 1991; Terradillos et al, 1997) and induces hepatocyte transformation in culture (Seifer et al, 1991).

\footnotetext{
*Correspondence: Dr E Song; E-mail: songerwei02@yahoo.com.cn or

Dr J Wang; E-mail: sumsjw@yahoo.com.cn

3 These authors contributed equally to this work.

Received 3 December 2010; revised 27 April 2011; accepted 5 May 20I I; published online 3I May 20II
}

Increasing evidence has demonstrated that non-coding RNAs (ncRNAs) are a new class of functional transcripts in eukaryotic cells (Costa, 2005), including microRNAs (miRNAs), which are 21- to 23-nucleotide RNA molecules that regulate the stability or translational efficiency of target mRNAs (Bartel, 2009). Primary miRNA transcripts (pri-miRNAs) are sequentially processed by two RNase III enzymes, Drosha and Dicer, to yield mature miRNAs (Kim, 2005). microRNAs are deregulated in many human diseases, especially in tumourigenesis. The pattern of miRNA expression can be correlated with cancer type, stage, and other clinical variables. microRNA expression analyses have also suggested oncogenic (or tumour-suppressive) roles of miRNAs. Of note, miRNAs have roles in almost all aspects of cancer biology, such as proliferation, apoptosis, invasion/metastasis, and angiogenesis (Lee and Dutta, 2009). The location of miRNAs in cancerassociated genomic regions, epigenetic mechanisms, and alterations in the miRNA processing machinery all contribute to the widespread differential expression of miRNA genes in malignant cells compared with normal cells (Calin and Croce, 2006).

Recently, miRNAs have been confirmed to function in viral pathogenesis by regulating the expression of genes from both the viral and host genomes. Epstein-Barr virus (EBV) encodes its own miRNAs, whereas its oncoprotein, LMP-1, induces the expression 
of host miR-146a and miR-155 via activation of NF- $\kappa$ B to modulate the innate immune response to the virus-infected host cell (Motsch et al, 2007). Similarly, human T-lymphotropic virus type I (HTLV-1) transforms host cells by inducing dysregulation of the expression of specific miRNAs, including miR-146a, which is upregulated by Tax (an oncoprotein of HTLV-1) (Pichler et al, 2008). Furthermore, miR-193b expression is induced by the hepatitis $\mathrm{C}$ virus (HCV), and this expression facilitates chemosensitivity to sorafenib in malignant hepatocytes (Braconi et al, 2010).

In this study, we first hypothesised that $\mathrm{HBx}$ expression in hepatocytes would alter host cellular miRNA expression, leading to HCC initiation and progression. We identified the significantly changed miRNAs ( $>2$-fold) between HepG2-hbx and HepG2-vc cells via microarray. The expression of $\mathrm{HBx}$ caused widespread miRNA repression in HepG2 cells, including the miR-16 family. Members of this family are frequently downregulated in multiple haematopoietic and solid tumours, including HCC (Huang et al, 2009), and this prompted us to further research regarding their repression. Downregulation of the miR-16 family was validated by quantitative reverse-transcription polymerase chain reaction (qRT-PCR) analysis of the HepG2, Huh7, and SK-HEP-1 cells that expressed HBx. According to these results, CCND1, a target of the miR-16 family, was derepressed in HepG2-hbx cells. Next, we confirmed that the induction of host $\mathrm{c}$-Myc mediated the suppression of miR-15a/16 in HepG2-hbx cells. Finally, we found that ectopically expressed miR-15a/16 suppressed the proliferation, clonogenicity, and anchorage-independent growth of HBx-expressing HepG2 cells by arresting cells in the G1 phase and inducing apoptosis, while the miR-16 inhibitor promoted the growth and cell-cycle progression of HepG2 cells.

\section{MATERIALS AND METHODS}

\section{Cell culture}

The human HepG2, SK-HEP-1, and Huh7 HCC cell lines were purchased from American Type Culture Collection (ATCC, Manassas, VA, USA) and cultured in Dulbecco's modification of Eagle's medium (DMEM; Gibco, Carlsbad, CA, USA) supplemented with $10 \%$ fetal bovine serum (FBS; HyClone, South Logan, UT, USA). The cells were cultured in DMEM supplemented with $10 \%$ FBS and $500 \mathrm{ng} \mathrm{ml}^{-1}$ G418 (Invitrogen, Carlsbad, CA, USA) (HepG2-hbx/HepG2-2.1, cells stably expressing HBx protein and HepG2-vc, cells stably transfected with PCDNA3.1 plasmid) or $380 \mathrm{ng} \mathrm{ml}^{-1}$ G418 (HepG2.2.15, HepG2 cells stably transfected with the entire HBV genome). All cell lines were maintained in a humidified atmosphere with $5 \% \mathrm{CO}_{2}$.

\section{RNA oligoribonucleotides and plasmids}

The HBx open reading frame (Adr subtype, AB299858) was cloned into the PCDNA3.1 $(+)$ plasmid (Invitrogen) to create PCDNA3.1hbx. All RNA oligoribonucleotides, including miR-15a/16 mimics/ inhibitors, c-Myc-specific siRNA, and negative control small RNAs (NC), were purchased from GenePharma (Shanghai, China).

\section{Cell transfection}

RNA oligoribonucleotides and plasmids were transfected using Lipofectamine 2000 (Invitrogen), according to the manufacturer's instructions. $200 \mathrm{nM}$ of miR-16 inhibitor and inhibitor NC, or 50 $\mathrm{nM}$ of other RNA oligoribonucleotides was used in cell transfection. For stable transfection, HepG2 cells were exposed to $900 \mathrm{ng} \mathrm{ml}^{-1} \mathrm{G} 41824 \mathrm{~h}$ after transfection with PCDNA3.1-hbx or PCDNA3.1. G418-resistant cells were further cultured to select the $\mathrm{HBx}$ mRNA- and protein-expressing monoclones.

\section{Reverse-transcription polymerase chain reaction and qRT-PCR}

Total RNA was extracted with TRIzol reagent (Invitrogen) and treated with DNase I (Tiangen Biotech, Beijing, China). cDNA for reverse-transcription polymerase chain reaction (RT-PCR) was synthesised with the PrimeScript RT-PCR kit (Takara Biotechnology, Dalian, China). The PCR amplification procedure for $\beta$-actin was as follows: $94^{\circ} \mathrm{C}$ for $3 \mathrm{~min} ; 30$ cycles of $94^{\circ} \mathrm{C}$ for $40 \mathrm{~s}, 56^{\circ} \mathrm{C}$ for $45 \mathrm{~s}$, and $72^{\circ} \mathrm{C}$ for $60 \mathrm{~s}$; followed by terminal elongation at $72^{\circ} \mathrm{C}$ for $7 \mathrm{~min}$. The amplification of $\mathrm{HBx}$ was performed as follows: $95^{\circ} \mathrm{C}$ for $2 \mathrm{~min}$; 30 cycles of $95^{\circ} \mathrm{C}$ for $30 \mathrm{~s}, 62.5^{\circ} \mathrm{C}$ for $30 \mathrm{~s}$, and $72^{\circ} \mathrm{C}$ for $30 \mathrm{~s}$; followed by $72^{\circ} \mathrm{C}$ for $5 \mathrm{~min}$. The qRT-PCR assays were performed using the SYBR PrimeScript RT-PCR kit (Takara Biotechnology). The assay kits for U6, miR-27a, miR-21, miR-663, miR-15a, miR-15b, and miR-16 were purchased from GenePharma; the TaqMan miRNA assay kit for miR-16 was purchased from Ambion (Foster City, CA, USA). snoRNAs, including RNU48, RNU44, U47, and RNU6B, were also purchased from Ambion and used as endogenous controls.

\section{Immunoblots}

Cell cytosolic protein fractions were prepared using RIPA buffer (Beyotime Biotechnology, Haimen, China). The antibodies used in western blotting were HBx (sc-71239; Santa Cruz Biotechnology, Santa Cruz, CA, USA), $\beta$-actin (sc-130301; Santa Cruz), c-Myc (9402; Cell Signaling Technology (CST), Boston, MA, USA), CCND1 (2926; CST), and GAPDH (BA2913; Wuhan Boster Biological Technology, Wuhan, China).

\section{miRNA microarrays}

The method for the miRNA microarray analysis was described in our previous report, except for the addition of an updated miRNA probe set (the NCode Human miRNA Microarray Probe Set V3+, Invitrogen) composed of 703 known and 393 predicted human miRNAs in the present work (Yu et al, 2007).

\section{Cell viability and apoptosis analysis}

Cell proliferation was analysed with the Cell Counting Kit-8 (CCK-8; Dojindo Laboratories, Kumamoto, Japan). The sphere formation assay was performed by culturing the cells $\left(1000\right.$ cells ml $\left.^{-1}\right)$ in suspension in serum-free DMEM-F12 supplemented with B27 (1:50, Invitrogen), $20 \mathrm{ng} \mathrm{ml}^{-1}$ EGF (BD Biosciences, San Jose, CA, USA), $0.4 \%$ bovine serum albumin (Sigma, St Louis, MO, USA), and $4 \mathrm{mg} \mathrm{ml}^{-1}$ insulin (Sigma). For the clonogenicity analysis, $24 \mathrm{~h}$ after transfection, aliquots of 500 viable HepG2-hbx cells or 1000 viable HepG2.2.15 cells were placed in 6-cm dishes and maintained in $10 \mathrm{ml}$ of complete medium for $2-3$ weeks. Cell apoptosis was determined $48 \mathrm{~h}$ after the NC and miR-15a/16 mimic transfections using an Annexin V-FITC kit (Bender MedSystems, Vienna, Austria) and analysed using a BD FACSCalibur flow cytometer (Becton Dickinson, San Jose, CA, USA).

\section{Cell-cycle analysis}

Twenty-four hours after the miRNA mimic and NC transfections, the cells were treated with nocodazole $\left(100 \mathrm{ng} \mathrm{ml}^{-1}\right.$, M1404; Sigma) for $20 \mathrm{~h}$. Floating and adherent cells were harvested, combined, washed once in phosphate-buffered saline, and fixed in $70 \%$ ethanol overnight. The DNA content was then examined using the Cell Cycle Detection Kit (KGA512; KeyGen Biotechnology, Nanjing, China) and analysed using BD FACSCalibur flow cytometer. 


\section{Luciferase reporter assay}

PGL3cm-CCND1-3'UTR wild-type and pGL3cm-CCND1-3'UTR mutant vectors were received as generous gifts from Dr Shi-Mei Zhuang (School of Life Sciences, Sun-Yat-sen University) and were constructed as previously described (Xu et al, 2009). HepG2-hbx and HepG2-vc cells were grown in 48-well plates and were cotransfected with $2 \mathrm{ng}$ of pRL-TK (Promega, Madison, WI, USA) and $5 \mathrm{ng}$ of wild-type or mutant luciferase reporter. Forty-eight hours after transfection, the cells were harvested and subjected to a luciferase assay. The firefly luciferase activity was normalised to the Renilla luciferase activity.

The sequence of RNA and DNA oligoribonucleotides used can be found in Supplementary Table 1.

\section{RESULTS}

\section{Establishing the HepG2-hbx, HepG2-2.1 and HepG2-vc cell lines}

To investigate the impact of HBx on host miRNA expression in HepG2 cells, we made stably expressing clones. We transfected the HBx-expressing plasmid (HepG2-hbx or HepG2-2.1) or empty vector (HepG2-vc) into the HepG2 cells and then performed G418 selection. Clones including HepG2-2.10 were screened for $\mathrm{HBx}$ mRNA and protein expression (Figures $1 \mathrm{~A}$ and $\mathrm{B}$ ). Over time, the expression of $\mathrm{HBx}$ increased the size and number of anchorageindependent colonies in the HepG2-hbx cells to a greater degree than in the HepG2-vc cells (Figures 1C and D).

\section{Members of the miR-16 family were frequently suppressed by $\mathrm{HBx}$ expression in HepG2, Huh7, and SK-HEP-1 cells}

The miRNA microarrays were analysed to identify the $\mathrm{HBx}$ deregulated miRNAs in HepG2 cells. The results showed that of the 1096 miRNAs included in the assay, HBx caused widespread suppressions of miRNA expression, including the miR-16 family, in the HepG2-hbx cells compared with the HepG2-vc cells ( $>2$-fold). Interestingly, few miRNAs, including miR-21, were upregulated by HBx expression. Therefore, further studies will be necessary to determine whether $\mathrm{HBx}$ impairs the biogenesis of miRNAs in HepG2 cells (Kumar et al, 2007). The detailed results of the microarray analysis are provided in Supplementary Table 2.

Because the miR-16 family has been reported to have multiple roles in tumour suppression (Bonci et al, 2008), we used qRT-PCR analysis to examine the expression of miR-16 family members in HepG2 cells that had been stably or transiently transfected with HBx. We found that the expression of these genes was significantly suppressed in both stably and transiently transfected cells (Figures $2 \mathrm{~A}$ and $\mathrm{B}$ ). To eliminate the deviation induced by using RNU6B as endogenous control, we further validated the $\mathrm{HBX}$-mediated downregulation of miR-16 in HepG2 cells using the TaqMan miRNA assay, which was normalised to the means of the endogenous controls, including RNU48, RNU44, U47, and RNU6B (Supplementary Figure 1). To explore whether the $\mathrm{HBx}$-mediated repression of the miR-16 family was reproducible or restricted to HepG2 cells, we transiently transfected PCDNA3.1-hbx and the control vector into non-HBV-infected Huh7 and SK-HEP-1 cells. Significantly, $\mathrm{HBx}$ also reduced the expression of the miR-16 family in both cell lines (Figures $2 \mathrm{C}$ and $\mathrm{D}$ ). In confirmation of the microarray results, we successfully detected the $\mathrm{HBx}$-induced downregulation of $\mathrm{miR}-27 \mathrm{a} / \mathrm{miR}-663$ and the upregulation of miR21 in HepG2 cells (Supplementary Figure 2).

To analyse whether the effects of HBx could be detected as far downstream as the target genes of miR-16 family members, we examined the expression of CCND1, a reported target of the miR-16 family, which functions in the G1/S transition of the cell cycle. Using a luciferase assay, we demonstrated that $\mathrm{HBx}$ significantly upregulated the activity of the CCND1 $3^{\prime} \mathrm{UTR}$ in HepG2-hbx compared with HepG2-vc cells ( $38 \pm 5 \%$; Figure 2E). Western blot results also confirmed the upregulation of CCND1 in HBx-expressing HepG2 cells (Figure 2F). These results were in accordance with reports that $\mathrm{HBx}$ stimulated cell-cycle progression (Benn and Schneider, 1995) and activated the expression of CCND1 (Klein et al, 2003; Park et al, 2006; Jung et al, 2007).

In addition, we found that miR-16 exhibited an inverse upregulation when $\mathrm{HBx}$ achieved pro-apoptotic doses during transient transfection (Supplementary Figure 3). More apoptotic cells appeared when we increased the dose of PCDNA3.1-hbx in HepG2, Huh7, and SK-HEP-1 cells (data not shown). This finding

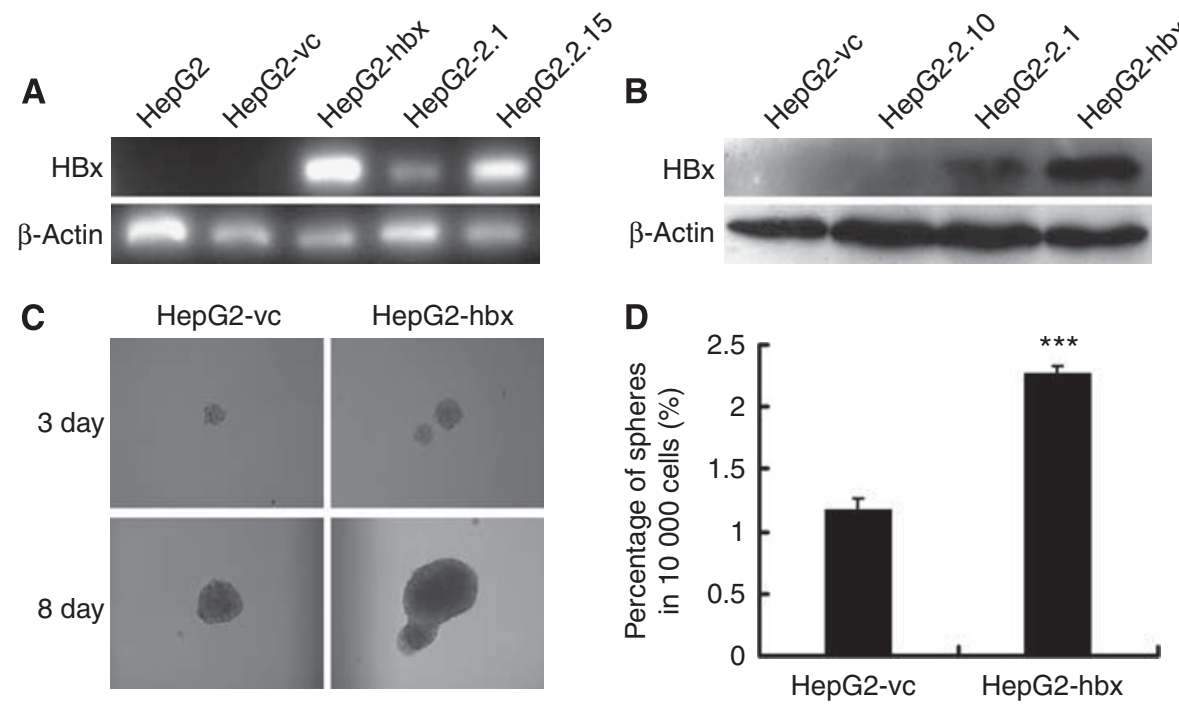

Figure I Generation of HepG2 cell lines stably expressing the HBx gene. (A) RT-PCR and (B) western blot analysis confirmed the mRNA and protein expression, respectively, of the HBx gene in the HepG2-hbx and HepG2-2.I cell lines. HepG2 cells stably transfected with vector alone (HepG2-vc) were used as a negative control. (C, D) HepG2-hbx cells produced significantly larger and more numerous spheres in an anchorage-independent sphere formation assay than did HepG2-vc under serum-free conditions. Representative graphs are presented. The data are presented as mean numbers of spheres \pm s.e. $($ ***** $P<0.00$ I; Student's t-test, $n=3$ ). 

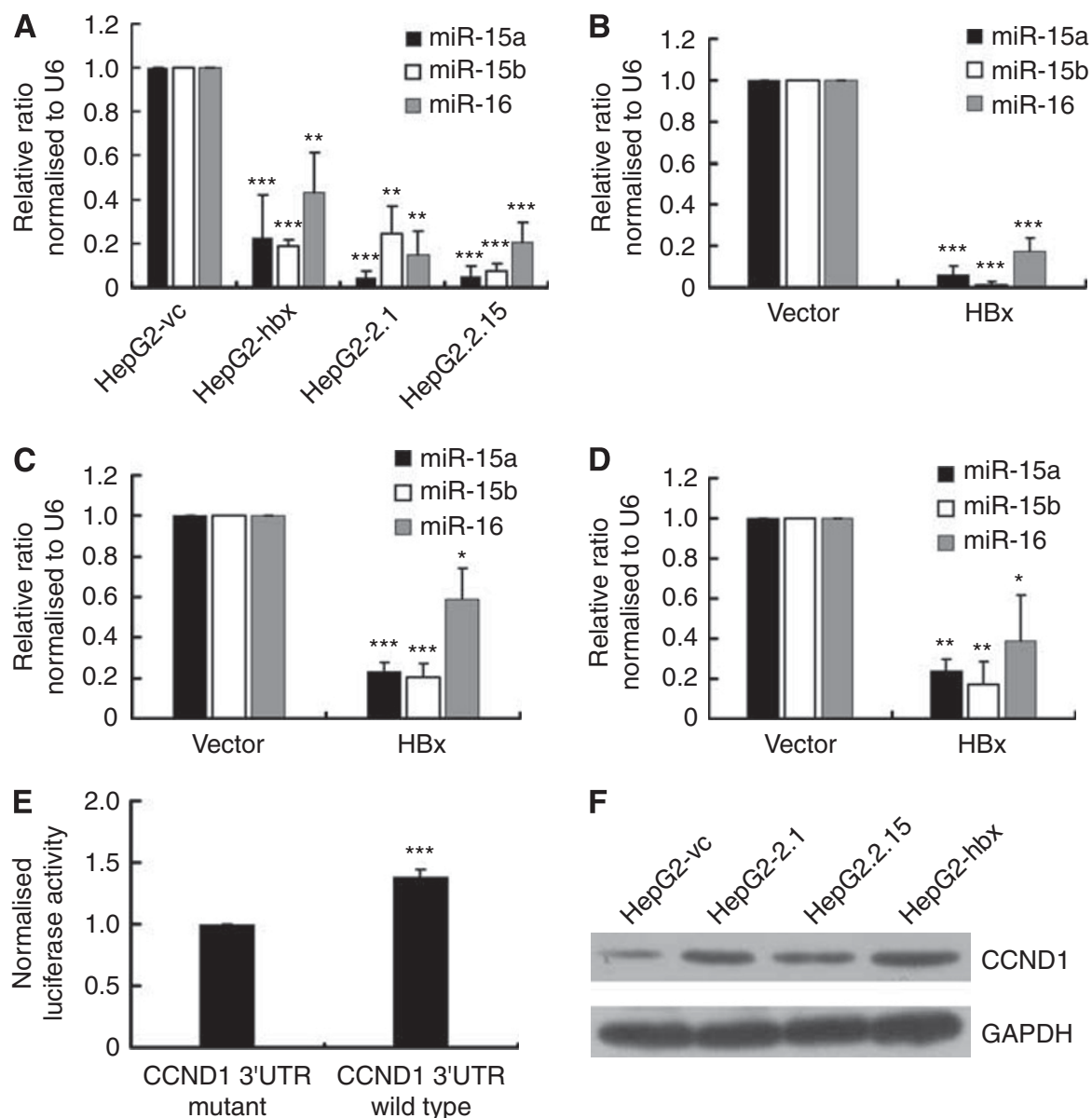

$\mathbf{F}$

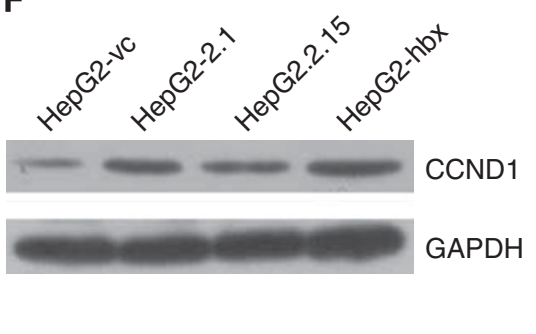

Figure $2 \mathrm{HBx}$ downregulates the expression of the miR-I 6 family in non-HBV-infected malignant hepatocytes in vitro and upregulates the expression of CCND I in HepG2 cells. (A) The expression of the miR-16 family was measured using qRT-PCR and normalised by U6 expression in HepG2 cells that stably expressed HBx or control vector. (B-D) The expression of the miR-16 family normalised to U6 was detected by qRT-PCR in (B) HepG2, (C) Huh7, and (D) SK-HEP-I cells transiently transfected with HBx-expressing plasmid or control vehicle. Each cell line was transfected with $4 \mu \mathrm{g}$ PCDNA3.I-hbx or $4 \mu \mathrm{g}$ PCDNA3.I as a control. Cells were collected for analysis $48 \mathrm{~h}$ after each transfection. (E) The activity of the luciferase reporter containing the wild-type 3'UTR of CCND I was elevated in HepG2-hbx cells. pRL-TK was co-transfected with a firefly luciferase reporter plasmid carrying either the wild-type (WT) or mutant (MUT) 3'UTR of CCNDI into HepG2-hbx or HepG2-vc cells; luciferase activity was analysed $48 \mathrm{~h}$ later. pRL-TK expressing Renilla luciferase was used to correct for the differences in transfection and harvest efficiencies between the HepG2-hbx and HepG2-vc cells. The ratio of the luciferase activity of MUT-3'UTR in HepG2-hbx to that in HepG2-vc cells was normalised to I. (F) A western blot confirmed the induction of CCNDI by HBx in HepG2 cells. The data are presented as mean \pm s.e. fold. ( $* P<0.05$, $* * P<0.0$ I, $* * * P<0.00$ I; Student's $t$-test, NPar tests; $n=3$ ).

may be attributed to the pro-apoptotic functions of both $\mathrm{HBx}$ (Terradillos et al, 1998; Arbuthnot et al, 2000) and miR-16 via the targeting of BCL-2 (Cimmino et al, 2005). More studies are needed to clarify the roles played by miR-16 in $\mathrm{HBx}$-induced hepatocyte apoptosis (or the inhibition of apoptosis) and acute/chronic HBV infection.

Taken together, these results show that $\mathrm{HBx}$ causes global miRNA deregulation in HepG2 cells and that the miR-16 family is frequently repressed by HBx expression in HepG2, Huh7, and SK-HEP-1 cells. Accordingly, CCND1, a target of the miR-16 family, is derepressed by HBx in HepG2 cells.

\section{Loss-of-function of c-Myc restored the expression of miR-15a/16 in HepG2-hbx cells}

To elucidate the underlying mechanisms of HBx-induced miR-16 family downregulation, we referred to a previous report showed that c-Myc repressed the promoter activity of pri-miR-15a/16-1 in B-cell lymphomas (Chang et al, 2008). We examined the expression of c-Myc in HepG2 cell lines stably transfected with HBx. Consistent with others' results (Balsano et al, 1991; Kalra and
Kumar, 2006; Li et al, 2010), HBx significantly upregulated the mRNA and protein expression of c-Myc in HepG2 cells (Figures $3 \mathrm{~A}$ and $\mathrm{B}$ ). As anticipated, the knock-down of c-Myc with a specific siRNA produced a remarkable rescue of the expression of miR-15a and miR-16 in HepG2-hbx cells at the indicated time points (Figure 3C). Of note, miR-15a was more sensitive to si-c-Myc treatment than was miR-16, which suggested that other mechanisms may be involved in the regulation of miR-16. This restoration could be reproduced in HepG2.2.15 cells (data not shown). These results suggest that HBx downregulates miR-15a/16 expression, at least partly, through the induction of c-Myc in HepG2 cells.

\section{Reduced expression of miR-16 promoted the growth and} cell-cycle progression of HepG2 cells

Although the tumour-suppressive capacity of the miR-16 family has been well documented in other cancers, a loss-of-function assay was performed to determine the consequences of such repression in HepG2 cells. We knocked down miR-16 expression in HepG2 cells using a specific antisense inhibitor, and CCK-8 
A

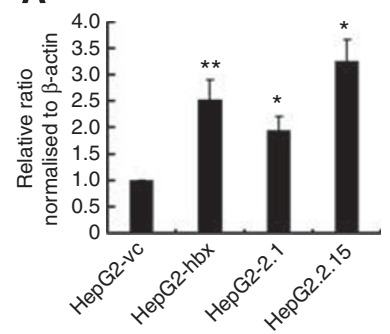

B

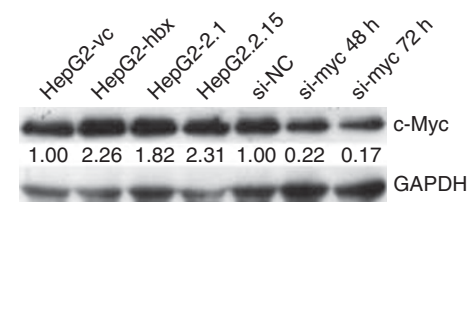

C

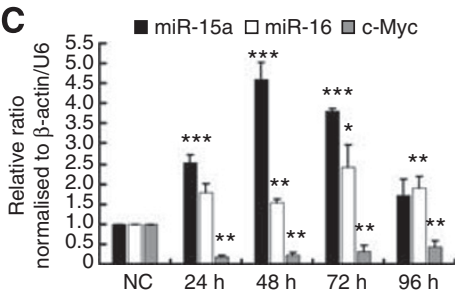

Figure $3 \mathrm{HB} \times$ suppresses the expression of miR-15a/l6 by activating c-Myc in HepG2 cells. (A) qRT-PCR and (B) representative western blot results showed that HBx upregulated c-Myc transcription and translation in HepG2 cells. Relative c-Myc expression was normalised to $\beta$-actin and GAPDH. The qRT-PCR data are presented as mean \pm s.e. fold compared with HepG2-vc ( $n=3$, Student's $t$-test). The c-Myc/GAPDH ratio is listed for the western blots. (C) The relative expression of c-Myc and miR-I5a/I6 was analysed by qRT-PCR at 24, 48, 72, and $96 \mathrm{~h}$ after the transfection of si-c-Myc into HepG2-hbx cells compared with the negative control (NC) siRNA transfectants, normalised to $\beta$-actin and U6, respectively. The data are presented as mean fold change \pm s.e. $(* P<0.05$, $* * P<0.01$, *** $P<0.001 ; n=3$, Student's t-test).
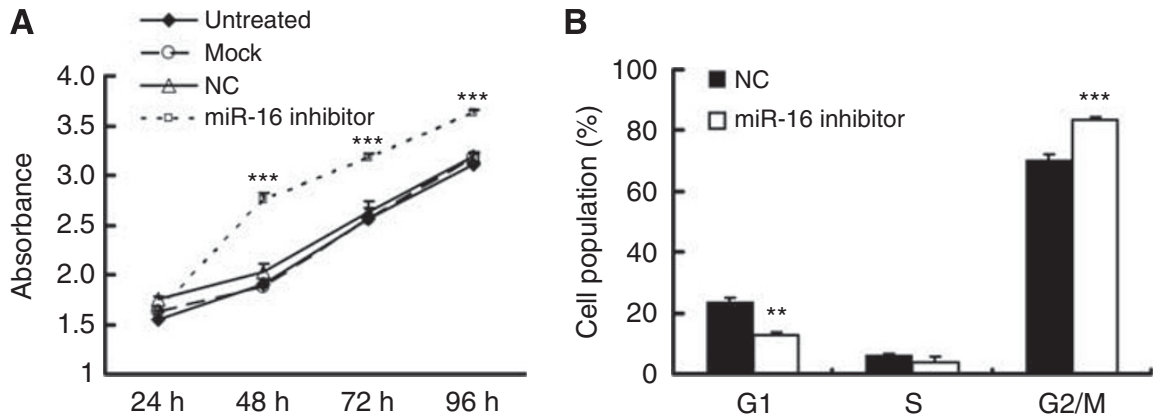

Figure 4 The miR-16 inhibitor promoted proliferation and cell-cycle progression in HepG2 cells. (A) The growth curves of HepG2 cells transfected with miR-16 inhibitor or NC were generated using the absorbance from the CCK-8 analysis at the indicated time points. The reduced expression of miR-I6 significantly promoted the growth of HepG2 cells at 48, 72, and $96 \mathrm{~h}$ post-transfection. (B) HepG2 cells were treated with nocodazole ( $100 \mathrm{ng} \mathrm{ml}^{-1}$ ) $24 \mathrm{~h}$ after the transfection of miR-16 inhibitor or NC, and cell-cycle distribution was analysed $20 \mathrm{~h}$ later. The data are presented as mean fold change \pm s.e. (*** $P<0.01$, ***** $P<0.001 ; n=3$, Student's t-test).

analysis showed that this miR-16 inhibitor significantly promoted cell proliferation at 48,72 , and $96 \mathrm{~h}$ post-transfection compared with the NC transfectants (Figure 4A). miR-16 inhibition also accelerated the G1/S transition in HepG2 cells (Figure 4B). The efficiency of the inhibitor was checked by qRT-PCR analysis (Supplementary Figure 4).

\section{Ectopically expressed $\mathrm{miR}-15 \mathrm{a} / 16$ suppressed the proliferation, clonogenicity, and anchorage-independent growth of HBx-expressing HepG2 cells by arresting cells at the G1 phase and inducing apoptosis}

To inspect the therapeutic potential of the miR-16 family in $\mathrm{HBV}^{+}$ HCC, a series of in vitro experiments were performed. CCK-8 analysis showed that miR-15a/16 mimics repressed the growth of HepG2-hbx cells at 72 and $96 \mathrm{~h}$ post-transfection compared with NC-transfected cells (Figure 5A). Subsequently, HepG2-hbx and HepG2.2.15 cells were transfected with NC or miR-15a/16 mimics and were allowed to form foci at a low density. Notably, fewer colonies were seen in miR-15a/16 mimic-transfected HepG2-hbx and HepG2.2.15 cells compared with NC transfectants (Figure 5B). We further analysed the effects of miR-15a/16 on anchorageindependent growth in a serum-free medium. The results showed that miR-15a/16 expression in HepG2-hbx cells significantly reduced the size and number of the spheres compared with the $\mathrm{NC}$ transfectants (Figures $5 \mathrm{C}$ and $\mathrm{D}$ ).

Next, we explored the mechanisms of the reduced survival of HepG2-hbx cells treated with miR-15a/16 mimics. Fluorescenceactivated cell sorting results showed that the enforced expression of miR-15a/16 caused an accumulation of cells during the G1 phase in HepG2-hbx cells (Figure 5E). Moreover, miR-15a/16 mimics also induced significantly more apoptotic cells than NC transfectants in HepG2-hbx cells (Figure 5F). Collectively, these results illustrate that the miR-16 family could efficiently repress the proliferation and viability of HepG2-hbx cells by blocking cell-cycle progression and inducing apoptosis.

\section{DISCUSSION}

Hepatitis $B$ virus $\mathrm{X}$ protein alters the expression of the host protein-coding genes by its transactivating function, thus contributing to the initiation and progression of HCC. However, most human genome transcripts are ncRNAs, including miRNAs, small RNAs, and long ncRNAs, all of which have been confirmed to be capable of regulating gene expression. The dysregulation of miRNAs and long ncRNAs is extensively involved in many human disease processes, including tumourigenesis (Matouk et al, 2007; Mercer et al, 2009; Wilusz et al, 2009; Gupta et al, 2010). At present, there have been few publications regarding the associations between $\mathrm{HBx}$ and host cellular miRNAs. In this study, we demonstrated that $\mathrm{HBx}$ altered host miRNA expression in malignant hepatocytes in vitro, including the c-Myc-mediated downregulation of miR-15a/16. Loss- and gain-of-function assays indicated the significance of miR-16 family deregulation in HepG2 cells transformed in vitro.

Hepatitis B virus X protein was found to cause widespread suppression of miRNAs expression, including the miR-16 family, 
A

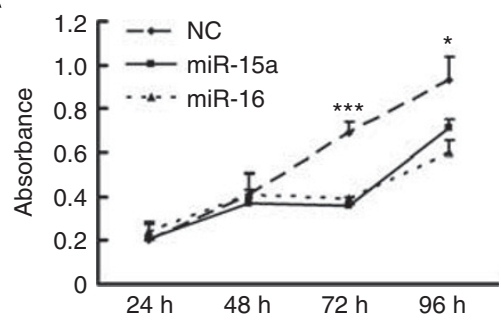

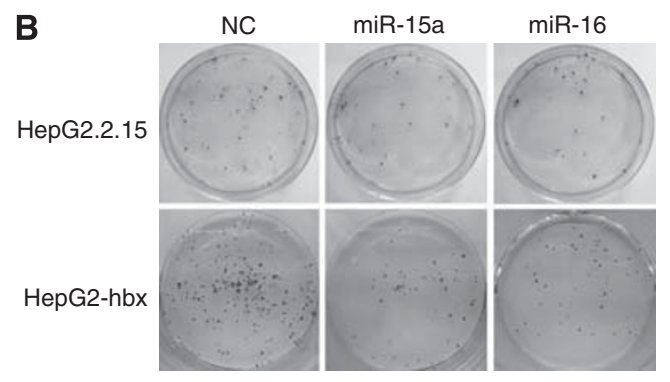

B
C

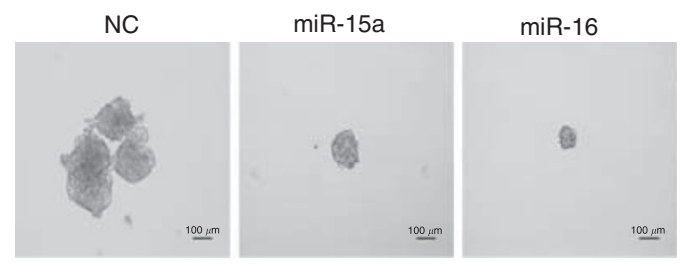

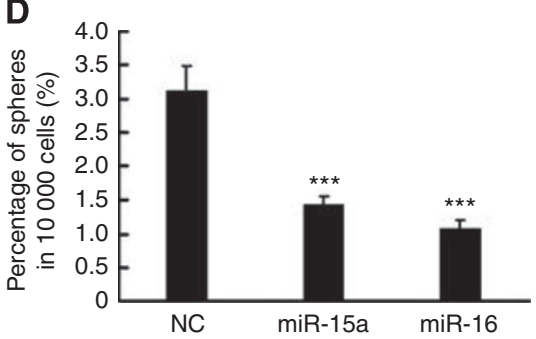
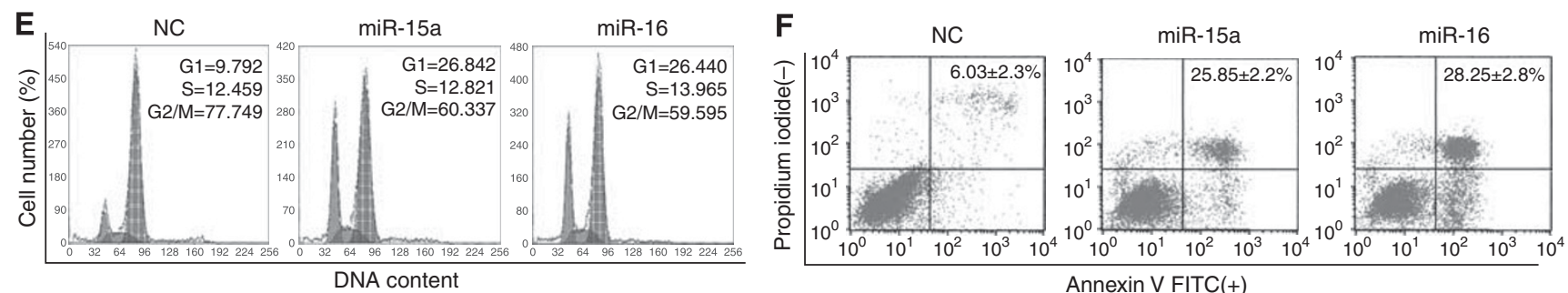

Figure 5 Ectopically expressed miR- I5a/I6 repressed the proliferation, clonogenicity, and anchorage-independent growth of HBx-transfected HepG2 cells in vitro by blocking cell-cycle progression and inducing apoptosis. (A) CCK-8 analysis showed that the expression of both miR-I5a and miR-I6 significantly suppressed the growth of HepG2-hbx cells at 72 and $96 \mathrm{~h}$ post-transfection. The data are presented as mean absorbance \pm s.e. (*P $<0.05$, **** $P<0.00$ I, $n=3$; Student's t-test). (B) HepG2-hbx and HepG2.2.15 cells transfected with miR-I5a/I 6 or NC were grown at an extremely low density (e.g., $500-1000$ cells in $10 \mathrm{ml}$ of medium) for $2-3$ weeks, and the clones were fixed with methanol and stained with $0.1 \%$ crystal violet in $20 \%$ methanol. Representative plates are presented. (C and D) HepG2-hbx cells (I0000) transfected with miR-I5a/I6 mimic or NC were placed in a I0-ml sphere formation assay-conditioned medium to grow anchorage independently for 10 days. The data are presented as the mean numbers of spheres \pm s.e. (**** $P<0.00 \mathrm{I} ; n=3$, Student's $t$-test). (E) HepG2-hbx cells were treated with nocodazole $\left(\mathrm{I} 00 \mathrm{ng} \mathrm{ml}^{-1}\right) 24 \mathrm{~h}$ post-transfection, and the DNA ploidy was analysed $20 \mathrm{~h}$ later. $2 \mathrm{~N}$, cells containing diploid DNA; $4 \mathrm{~N}$, cells containing tetraploid DNA. (F) PI-Annexin $\mathrm{V}$ analysis was performed to detect the early apoptosis of HepG2-hbx cells transfected with miR-15a/l6 or NC $(48 \mathrm{~h})$. The data are presented as mean \pm s.e. $(n=3)$.

in HepG2 cells, but the upregulation of only a few miRNAs. This miRNA expression pattern is considered to be a specific characteristic of tumours (Bottoni et al, 2005; Calin and Croce, 2006; Kumar et al, 2007). The downregulation of miR-15a, -16, -338, and -422a has also been reported by Liu et al (2009). They identified HBV-associated miRNAs differentially expressed between HepG2.2.15 and the parental HepG2 cells using microarrays and northern blot analyses. In the present study, we directly transfected $\mathrm{HBx}$ into HepG2 cells to establish clones that stably expressed $\mathrm{HBx}$ and demonstrated that the expression of the miR-16 family was downregulated in HepG2 cells and HepG2.2.15 cells (Figure 2A). However, HepG2.2.15, which is a HepG2 cell line transfected with a plasmid carrying four $5^{\prime}-3^{\prime}$ tandem copies of the $\mathrm{HBV}$ genome, still did not completely simulate natural $\mathrm{HBV}$ infection, as multiple copies of HBV DNA were integrated into the stably transfected line (Sells et al, 1987). This is likely to influence cell function, and the role of the miR-16 family in HBV infection in vivo remains to be further investigated.

The miR-16 family is composed of miR-15a, $-15 b$, and -16 . The miR-15a/16-1 and miR-15b/16-2 gene clusters are located on human chromosomes $13 \mathrm{q}$ and 3 and are co-transcribed with DLEU2 and SMC4, respectively (Yue and Tigyi, 2010). This family generally functions as a key regulator of the G1/S cell-cycle checkpoint by targeting CCND1-3, CCNE1, and CDK6 (Linsley et al, 2007; Liu et al, 2008). Accordingly, the deletion of 13q (the location of miR-15a/16-1) is associated with the deregulation of genes involved in the cell cycle and proliferation in dedifferentiated HCCs (Skawran et al, 2008) and is also related to aggressive HCC behaviours (Wong et al, 2002). This family has also been shown to be repressed and to suppress (in specific tumour types) a series of oncogenes that include $c-M y b, B m i-1$, $B C L-2$, WNT3A, and Wip1 (Bottoni et al, 2005; Cimmino et al, 2005; Bonci et al, 2008; Bandi et al, 2009; Bhattacharya et al, 2009; Zhao et al, 2009; Zhu et al, 2009; Klein et al, 2010; Meyer-Rochow et al, 2010; Zhang et al, 2010). Moreover, members of the miR-16 family are involved in regulating chemosensitivity (Blower et al, 2008; Xia et al, 2008). With respect to HCC, the downregulation of miR-15a and miR-16-1 is a valuable predictor of HCC venous metastasis and patient survival (Budhu et al, 2008). High expression of miR-15b is correlated with a low risk of tumour recurrence following hepatectomy (Chung et al, 2010). In addition to hepatocytes, miR-15b and miR-16 are repressed during the activation of rat hepatic stellate cells (HSCs; Guo et al, 2009b), and miR-16 inhibits proliferation while increases the apoptosis of HSCs (Guo et al, 2009a). Importantly, $\mathrm{HBx}$ can induce paracrine activation and proliferation of HSCs in both human and rat liver via TGF- $\beta$ (Martin-Vilchez et al, 2008). Collectively, these data suggest that the suppression of the miR-16 family contributes to the initiation (i.e., liver fibrosis/cirrhosis) and progression of $\mathrm{HBV} /$ $\mathrm{HBx}$-induced HCCs. 
The miR-16 family is the downstream target of several oncogenic and tumour suppressor networks. p53 facilitates the maturation of the miR-15a/16-1 cluster (Suzuki et al, 2009), and the expression of miR-15b/16-2 cluster is directly induced by E2F1 and E2F3 during the G1/S transition (Bueno et al, 2010). Radiation also induces the upregulation of miR-15a/16 in glioblastoma cells (Chaudhry et al, 2010) and in human endothelial cells (WagnerEcker et al, 2010). In contrast, the expression of the miR-16 family has been shown to be suppressed $>1.5$-fold by c-Myc and lin28B in B-cell lymphomas (Chang et al, 2008, 2009), which mirrors the preliminary $\mathrm{HBx}-\mathrm{c}-\mathrm{Myc}-\mathrm{miR}-15 \mathrm{a} / 16$ pathway found in our study. c-Myc has been suggested to have a central role during the malignant transition in human hepatocarcinogenesis (KaposiNovak et al, 2009). Additionally, HER2 Delta 16 suppresses miR$15 \mathrm{a} / 16$ and deregulates BCL-2 to promote endocrine resistance in breast tumours (Cittelly et al, 2010), whereas PKC alpha downregulates miR-15a in head and neck squamous cell carcinoma (Cohen et al, 2009). Notably, because HBx can antagonise the function of p53 by itself (Dewantoro et al, 2006) or by recruiting c-Myc (Lee and Rho, 2000), we propose that HBx may induce c-Myc to repress the transcription and p53-mediated posttranscriptional maturation of miR-15a/16.

While this manuscript was being prepared, Wang et al (2010) reported for the first time that HBx induced the deregulation of cellular miRNAs in HepG2 cells and that the let-7 family was downregulated in both HBx-transfected cell lines and HBVinfected HCC tumour tissue (Wang et al, 2010). The miR-16 family was not included in their microarray analysis; however, the repression of let-7d ( $>2$-fold) was detected in our results. The

\section{REFERENCES}

Arbuthnot P, Capovilla A, Kew M (2000) Putative role of hepatitis B virus X protein in hepatocarcinogenesis: effects on apoptosis, DNA repair, mitogen-activated protein kinase and JAK/STAT pathways. J Gastroenterol Hepatol 15(4): $357-368$

Balsano C, Avantaggiati ML, Natoli G, De Marzio E, Will H, Perricaudet M, Levrero M (1991) Full-length and truncated versions of the hepatitis B virus (HBV) X protein ( $\mathrm{pX}$ ) transactivate the cmyc protooncogene at the transcriptional level. Biochem Biophys Res Commun 176(3): 985-992

Bandi N, Zbinden S, Gugger M, Arnold M, Kocher V, Hasan L, Kappeler A, Brunner T, Vassella E (2009) miR-15a and miR-16 are implicated in cell cycle regulation in a $\mathrm{Rb}$-dependent manner and are frequently deleted or down-regulated in non-small cell lung cancer. Cancer Res 69(13): $5553-5559$

Bartel DP (2009) MicroRNAs: target recognition and regulatory functions. Cell 136(2): 215-233

Benn J, Schneider RJ (1995) Hepatitis B virus HBx protein deregulates cell cycle checkpoint controls. Proc Natl Acad Sci USA 92(24): 11215-11219

Bhattacharya R, Nicoloso M, Arvizo R, Wang E, Cortez A, Rossi S, Calin GA, Mukherjee P (2009) MiR-15a and MiR-16 control Bmi-1 expression in ovarian cancer. Cancer Res 69(23): 9090-9095

Blower PE, Chung JH, Verducci JS, Lin S, Park JK, Dai Z, Liu CG, Schmittgen TD, Reinhold WC, Croce CM, Weinstein JN, Sadee W (2008) MicroRNAs modulate the chemosensitivity of tumor cells. Mol Cancer Ther 7(1): $1-9$

Bonci D, Coppola V, Musumeci M, Addario A, Giuffrida R, Memeo L, D’Urso L, Pagliuca A, Biffoni M, Labbaye C, Bartucci M, Muto G, Peschle C, De Maria R (2008) The miR-15a-miR-16-1 cluster controls prostate cancer by targeting multiple oncogenic activities. Nat Med 14(11): 1271-1277

Bottoni A, Piccin D, Tagliati F, Luchin A, Zatelli MC, degli Uberti EC (2005) miR-15a and miR-16-1 down-regulation in pituitary adenomas. $J$ Cell Physiol 204(1): 280-285

Braconi C, Valeri N, Gasparini P, Huang N, Taccioli C, Nuovo G, Suzuki T, Croce CM, Patel T (2010) Hepatitis C virus proteins modulate microRNA expression and chemosensitivity in malignant hepatocytes. Clin Cancer Res 16(3): $957-966$

Budhu A, Jia HL, Forgues M, Liu CG, Goldstein D, Lam A, Zanetti KA, Ye QH, Qin LX, Croce CM, Tang ZY, Wang XW (2008) Identification of disparities between these data may have resulted from differences in the $\mathrm{HBx}$ expression system (i.e., Wang et al employed a transient recombinant adenovirus infection, whereas we used stable transfection), differences in microarray sensitivity, and in the intensity of $\mathrm{HBx}$ protein expression.

In conclusion, we found that $\mathrm{HBx}$ altered the expression of cellular miRNAs in host malignant hepatocytes in vitro, including the repression of the miR-16 family. Furthermore, $\mathrm{HBx}$-induced downregulation of miR-15a/16 in HepG2 cells was c-Myc mediated, while ectopically expressed miR-15a/16 repressed the proliferation, clonogenicity, and anchorage-independent growth of HepG2-hbx cells by inducing cell-cycle arrest and apoptosis. Our results highlight the therapeutic roles that targeting c-Myc and the miR-16 family may play in HBV-related chronic liver diseases.

\section{ACKNOWLEDGEMENTS}

This work was supported by grants from the National Natural Science Foundation of China (Nos. 30772550, 30830110, 30831160515, 30921140312, and 30973396), 973 Projects from the Ministry of Science and Technology of China (Nos. 2010CB912800, 2009CB521706, and 2011CB504203), and the Natural Science Foundation of Guangdong Province (8251008901000011 and 10151008901000138).

Supplementary Information accompanies the paper on British Journal of Cancer website (http://www.nature.com/bjc) metastasis-related microRNAs in hepatocellular carcinoma. Hepatology (Baltimore, $M d$ ) 47(3): 897-907

Bueno MJ, Gomez de Cedron M, Laresgoiti U, Fernandez-Piqueras J, Zubiaga AM, Malumbres M (2010) Multiple E2F-induced microRNAs prevent replicative stress in response to mitogenic signaling. Mol Cell Biol 30(12): $2983-2995$

Calin GA, Croce CM (2006) MicroRNA signatures in human cancers. Nat Rev Cancer 6(11): $857-866$

Chang TC, Yu D, Lee YS, Wentzel EA, Arking DE, West KM, Dang CV, Thomas-Tikhonenko A, Mendell JT (2008) Widespread microRNA repression by Myc contributes to tumorigenesis. Nat Genet 40(1): $43-50$

Chang TC, Zeitels LR, Hwang HW, Chivukula RR, Wentzel EA, Dews M, Jung J, Gao P, Dang CV, Beer MA, Thomas-Tikhonenko A, Mendell JT (2009) Lin-28B transactivation is necessary for Myc-mediated let-7 repression and proliferation. Proc Natl Acad Sci USA 106(9): 3384-3389

Chaudhry MA, Sachdeva H, Omaruddin RA (2010) Radiation-induced micro-RNA modulation in glioblastoma cells differing in DNA-repair pathways. DNA Cell Biol 29(9): 553-561

Chung GE, Yoon JH, Myung SJ, Lee JH, Lee SH, Lee SM, Kim SJ, Hwang SY, Lee HS, Kim CY (2010) High expression of microRNA-15b predicts a low risk of tumor recurrence following curative resection of hepatocellular carcinoma. Oncol Rep 23(1): 113-119

Cimmino A, Calin GA, Fabbri M, Iorio MV, Ferracin M, Shimizu M, Wojcik SE, Aqeilan RI, Zupo S, Dono M, Rassenti L, Alder H, Volinia S, Liu CG, Kipps TJ, Negrini M, Croce CM (2005) miR-15 and miR-16 induce apoptosis by targeting BCL2. Proc Natl Acad Sci USA 102(39): $13944-13949$

Cittelly DM, Das PM, Salvo VA, Fonseca JP, Burow ME, Jones FE (2010) Oncogenic HER2 $\backslash$ Deltal\}16 suppresses miR-15a/16 and d. Carcinogenesis 31(12): 2049-2057

Cohen EE, Zhu H, Lingen MW, Martin LE, Kuo WL, Choi EA, Kocherginsky M, Parker JS, Chung CH, Rosner MR (2009) A feed-forward loop involving protein kinase $\mathrm{C}$ alpha and microRNAs regulates tumor cell cycle. Cancer Res 69(1): 65-74

Costa FF (2005) Non-coding RNAs: new players in eukaryotic biology. Gene 357(2): $83-94$ 
Dewantoro O, Gani RA, Akbar N (2006) Hepatocarcinogenesis in viral Hepatitis B infection: the role of $\mathrm{HBx}$ and $\mathrm{p} 53$. Acta Med Indones 38(3): $154-159$

El-Serag HB, Rudolph KL (2007) Hepatocellular carcinoma: epidemiology and molecular carcinogenesis. Gastroenterology 132(7): 2557-2576

Feitelson MA, Lee J (2007) Hepatitis B virus integration, fragile sites, and hepatocarcinogenesis. Cancer Lett 252(2): 157-170

Guo CJ, Pan Q, Jiang B, Chen GY, Li DG (2009a) Effects of upregulated expression of microRNA-16 on biological properties of culture-activated hepatic stellate cells. Apoptosis 14(11): 1331-1340

Guo CJ, Pan Q, Li DG, Sun H, Liu BW (2009b) miR-15b and miR-16 are implicated in activation of the rat hepatic stellate cell: An essential role for apoptosis. J Hepatol 50(4): 766-778

Gupta RA, Shah N, Wang KC, Kim J, Horlings HM, Wong DJ, Tsai MC, Hung T, Argani P, Rinn JL, Wang Y, Brzoska P, Kong B, Li R, West RB, van de Vijver MJ, Sukumar S, Chang HY (2010) Long non-coding RNA HOTAIR reprograms chromatin state to promote cancer metastasis. Nature 464(7291): $1071-1076$

Huang XH, Wang Q, Chen JS, Fu XH, Chen XL, Chen LZ, Li W, Bi J, Zhang LJ, Fu Q, Zeng WT, Cao LQ, Tan HX, Su Q (2009) Bead-based microarray analysis of microRNA expression in hepatocellular carcinoma: miR-338 is downregulated. Hepatol Res 39(8): 786-794

Jung JK, Arora P, Pagano JS, Jang KL (2007) Expression of DNA methyltransferase 1 is activated by hepatitis $B$ virus $X$ protein via a regulatory circuit involving the p16INK4a-cyclin D1-CDK 4/6-pRb-E2F1 pathway. Cancer Res 67(12): 5771-5778

Kalra N, Kumar V (2006) The X protein of hepatitis B virus binds to the $\mathrm{F}$ box protein Skp2 and inhibits the ubiquitination and proteasomal degradation of c-Myc. FEBS Lett 580(2): 431-436

Kaposi-Novak P, Libbrecht L, Woo HG, Lee YH, Sears NC, Coulouarn C, Conner EA, Factor VM, Roskams T, Thorgeirsson SS (2009) Central role of c-Myc during malignant conversion in human hepatocarcinogenesis. Cancer Res 69(7): 2775-2782

Kim CM, Koike K, Saito I, Miyamura T, Jay G (1991) HBx gene of hepatitis B virus induces liver cancer in transgenic mice. Nature 351(6324): $317-320$

Kim VN (2005) MicroRNA biogenesis: coordinated cropping and dicing. Nat Rev 6(5): 376-385

Klein A, Guhl E, Tzeng YJ, Fuhrhop J, Levrero M, Graessmann M, Graessmann A (2003) HBX causes cyclin D1 overexpression and development of breast cancer in transgenic animals that are heterozygous for p53. Oncogene 22(19): 2910-2919

Klein U, Lia M, Crespo M, Siegel R, Shen Q, Mo T, Ambesi-Impiombato A, Califano A, Migliazza A, Bhagat G, Dalla-Favera R (2010) The DLEU2/ miR-15a/16-1 cluster controls B cell proliferation and its deletion leads to chronic lymphocytic leukemia. Cancer Cell 17(1): 28-40

Kumar MS, Lu J, Mercer KL, Golub TR, Jacks T (2007) Impaired microRNA processing enhances cellular transformation and tumorigenesis. Nat Genet 39(5): 673-677

Lee SG, Rho HM (2000) Transcriptional repression of the human p53 gene by hepatitis B viral X protein. Oncogene 19(3): $468-471$

Lee YS, Dutta A (2009) MicroRNAs in cancer. Annu Rev Pathol 4: $199-227$

Li W, Miao X, Qi Z, Zeng W, Liang J, Liang Z (2010) Hepatitis B virus X protein upregulates HSP90alpha expression via activation of c-Myc in human hepatocarcinoma cell line, HepG2. Virol J 7: 45

Linsley PS, Schelter J, Burchard J, Kibukawa M, Martin MM, Bartz SR, Johnson JM, Cummins JM, Raymond CK, Dai H, Chau N, Cleary M, Jackson AL, Carleton M, Lim L (2007) Transcripts targeted by the microRNA-16 family cooperatively regulate cell cycle progression. Mol Cell Biol 27(6): 2240-2252

Liu Q, Fu H, Sun F, Zhang H, Tie Y, Zhu J, Xing R, Sun Z, Zheng X (2008) miR-16 family induces cell cycle arrest by regulating multiple cell cycle genes. Nucleic Acids Res 36(16): $5391-5404$

Liu Y, Zhao JJ, Wang CM, Li MY, Han P, Wang L, Cheng YQ, Zoulim F, Ma X, Xu DP (2009) Altered expression profiles of microRNAs in a stable hepatitis B virus-expressing cell line. Chin Med J 122(1): 10-14

Martin-Vilchez S, Sanz-Cameno P, Rodriguez-Munoz Y, Majano PL, Molina-Jimenez F, Lopez-Cabrera M, Moreno-Otero R, Lara-Pezzi E (2008) The hepatitis B virus X protein induces paracrine activation of human hepatic stellate cells. Hepatology (Baltimore, Md) 47(6): $1872-1883$
Matouk IJ, DeGroot N, Mezan S, Ayesh S, Abu-lail R, Hochberg A, Galun E (2007) The H19 non-coding RNA is essential for human tumor growth. PLoS One 2(9): e845

Mercer TR, Dinger ME, Mattick JS (2009) Long non-coding RNAs: insights into functions. Nat Rev Genet 10(3): 155-159

Meyer-Rochow GY, Jackson NE, Conaglen JV, Whittle DE, Kunnimalaiyaan M, Chen H, Westin G, Sandgren J, Stalberg P, Khanafshar E, Shibru D, Duh QY, Clark OH, Kebebew E, Gill AJ, Clifton-Bligh R, Robinson BG, Benn DE, Sidhu SB (2010) MicroRNA profiling of benign and malignant pheochromocytomas identifies novel diagnostic and therapeutic targets. Endocr Relat Cancer 17(3): 835-846

Motsch N, Pfuhl T, Mrazek J, Barth S, Grasser FA (2007) Epstein-Barr virusencoded latent membrane protein 1 (LMP1) induces the expression of the cellular microRNA miR-146a. RNA Biol 4(3): 131-137

Park SG, Chung C, Kang H, Kim JY, Jung G (2006) Up-regulation of cyclin D1 by $\mathrm{HBx}$ is mediated by NF-kappaB2/BCL3 complex through kappaB site of cyclin D1 promoter. J Biol Chem 281(42): 31770-31777

Pichler K, Schneider G, Grassmann R (2008) MicroRNA miR-146a and further oncogenesis-related cellular microRNAs are dysregulated in HTLV-1-transformed T lymphocytes. Retrovirology 5: 100

Seifer M, Hohne M, Schaefer S, Gerlich WH (1991) In vitro tumorigenicity of hepatitis B virus DNA and HBx protein. J Hepatol 13(Suppl 4): S61-S65

Sells MA, Chen ML, Acs G (1987) Production of hepatitis B virus particles in Hep G2 cells transfected with cloned hepatitis B virus DNA. Proc Natl Acad Sci USA 84(4): 1005 - 1009

Skawran B, Steinemann D, Becker T, Buurman R, Flik J, Wiese B, Flemming P, Kreipe H, Schlegelberger B, Wilkens L (2008) Loss of 13q is associated with genes involved in cell cycle and proliferation in dedifferentiated hepatocellular carcinoma. Mod Pathol 21(12): 1479-1489

Suzuki HI, Yamagata K, Sugimoto K, Iwamoto T, Kato S, Miyazono K (2009) Modulation of microRNA processing by p53. Nature 460(7254): $529-533$

Terradillos O, Billet O, Renard CA, Levy R, Molina T, Briand P, Buendia MA (1997) The hepatitis B virus X gene potentiates c-myc-induced liver oncogenesis in transgenic mice. Oncogene 14(4): 395-404

Terradillos O, Pollicino T, Lecoeur H, Tripodi M, Gougeon ML, Tiollais P, Buendia MA (1998) p53-independent apoptotic effects of the hepatitis B virus $\mathrm{HBx}$ protein in vivo and in vitro. Oncogene 17(16): 2115-2123

Wagner-Ecker M, Schwager C, Wirkner U, Abdollahi A, Huber PE (2010) MicroRNA expression after ionizing radiation in human endothelial cells. Radiat Oncol 5: 25

Wang Y, Lu Y, Toh ST, Sung WK, Tan P, Chow P, Chung AY, Jooi LL, Lee CG (2010) Lethal-7 is down-regulated by the hepatitis B virus $\mathrm{x}$ protein and targets signal transducer and activator of transcription 3. J Hepatol 53(1): $57-66$

Wilusz JE, Sunwoo H, Spector DL (2009) Long noncoding RNAs: functional surprises from the RNA world. Genes Dev 23(13): 1494-1504

Wong CM, Lee JM, Lau TC, Fan ST, Ng IO (2002) Clinicopathological significance of loss of heterozygosity on chromosome 13q in hepatocellular carcinoma. Clin Cancer Res 8(7): 2266-2272

Xia L, Zhang D, Du R, Pan Y, Zhao L, Sun S, Hong L, Liu J, Fan D (2008) miR-15b and miR-16 modulate multidrug resistance by targeting BCL2 in human gastric cancer cells. Int J Cancer 123(2): 372-379

Xu T, Zhu Y, Xiong Y, Ge YY, Yun JP, Zhuang SM (2009) MicroRNA-195 suppresses tumorigenicity and regulates G1/S transition of human hepatocellular carcinoma cells. Hepatology (Baltimore, Md) 50(1): $113-121$

Yu F, Yao H, Zhu P, Zhang X, Pan Q, Gong C, Huang Y, Hu X, Su F, Lieberman J, Song E (2007) let-7 regulates self renewal and tumorigenicity of breast cancer cells. Cell 131(6): 1109-1123

Yue J, Tigyi G (2010) Conservation of miR-15a/16-1 and miR-15b/16-2 clusters. Mamm Genome 21(1-2): 88-94

Zhang X, Wan G, Mlotshwa S, Vance V, Berger FG, Chen H, Lu X (2010) Oncogenic Wipl phosphatase is inhibited by miR-16 in the DNA damage signaling pathway. Cancer Res 70(18): 7176-7186

Zhao H, Kalota A, Jin S, Gewirtz AM (2009) The c-myb proto-oncogene and microRNA-15a comprise an active autoregulatory feedback loop in human hematopoietic cells. Blood 113(3): 505-516

Zhu JY, Pfuhl T, Motsch N, Barth S, Nicholls J, Grasser F, Meister G (2009) Identification of novel Epstein-Barr virus microRNA genes from nasopharyngeal carcinomas. J Virol 83(7): 3333-3341 